INVITED ARTICLE

\title{
Physiology of Oxygen Transport and its Determinants in Intensive Care Unit
}

\author{
Sumesh Arora ${ }^{1}$, Pratik Tantia ${ }^{2}$
}

\begin{abstract}
Transport of oxygen is one of the most important functions of blood. How oxygen moves from the air, where its partial pressure is about 150 $\mathrm{mm} \mathrm{Hg}$ to mitochondria, where it drops down to a single digit is an evolutionary marvel. In this article, we discuss the physiology of oxygen transport from the alveoli to the tissue, the alveolar gas equation and the oxyhemoglobin dissociation curve. In the applied physiology section, we discuss the impact of high altitude, hyperbaric conditions, carbon monoxide poisoning on the transport of oxygen. Some common pitfalls in the interpretation of pulse oximetry and arterial blood gas are also discussed. Finally, we talk about the methods of increasing oxygen delivery, the compensation for hypoxia and some indications of venous oxygen saturation measurement.

Keywords: Arterial blood gas analysis, Hemoglobin, Hyperbaric oxygen therapy, Hypoxia, Oxygen saturation, Pulse oximetry Indian Journal of Critical Care Medicine (2019): 10.5005/jp-journals-10071-23246
\end{abstract}

Oxygen is vital for functioning of every cell in the body. Oxygen needs to be transported from the atmospheric air to the mitochondria. In this article, we will review mechanism of oxygen transport in the blood, factors affecting oxygen delivery and the clinical implications of this knowledge in day-to-day practice. Table 1 consists of lists of abbreviations used in this article.

\section{Transport of Oxygen in Blood - From Alveoli to the Tissues}

While transport of oxygen from the atmosphere to mitochondria is a continuous process, for the purpose of discussion, we will divide it into smaller steps. The steps are outlined together in Flowchart 1.

\section{Oxygen in the Atmosphere}

Atmospheric air is a mixture of gases, wherein each constituent gas has a partial pressure which is the notional pressure of that gas if it were to occupy the entire volume of the gas mixture at the same temperature. Dalton's law of partial pressure states that the total pressure of a mixture of gases is equal to the sum of partial pressures of individual gases.

\section{Oxygen Reaches Alveoli}

Expected partial pressure of oxygen in the alveoli may be calculated using the alveolar gas equation:
${ }^{1}$ Department of Intensive Care Medicine, Prince of Wales Hospital, Sydney, New South Wales, Australia

${ }^{2}$ Department of Intensive Care, Ananta Institute of Medical Sciences and Research Centre, Rajsamand, Rajasthan, India

Corresponding Author: Sumesh Arora, Department of Intensive Care Medicine, Prince of Wales Hospital, Sydney, New South Wales, Australia, e-mail: sumesharora1@gmail.com

How to cite this article: Arora S, Tantia P. Physiology of Oxygen Transport and its Determinants in Intenstive Care Unit. Indian J Crit Care Med 2019;23(Suppl 3):S172-S177.

Source of support: Nil

Conflict of interest: Dr Arora is the Director of Quiz Time in Critical Care Pty Ltd, Sydney, Australia; which runs the website www. gotheextramile.com - MCQ in Critical Care. Dr Arora is not paid any salary for his work with Go the Extra Mile.

$$
\begin{aligned}
& \mathrm{PAO}_{2}=\mathrm{PiO}_{2}-\frac{\mathrm{PaCO}_{2}}{\mathrm{R}} \\
& \mathrm{PAO}_{2}=\mathrm{FiO}_{2}\left(\mathrm{~PB}-\mathrm{PH}_{2} \mathrm{O}\right)-\frac{\mathrm{PaCO}_{2}}{\mathrm{R}}
\end{aligned}
$$

\section{Oxygen Dissolves in Blood}

From alveoli, oxygen diffuses into blood. Dissolved oxygen in blood also exerts partial pressure. This pressure is labeled as $\mathrm{PaO}_{2}$ (Fig. 1). The solubility of oxygen in blood is directly proportional to the

\begin{tabular}{|c|c|c|c|}
\hline ABG & Arterial blood gas & $\mathrm{PiO}_{2}$ & Partial pressure of inspired oxygen \\
\hline atm & Atmospheres pressure & $\mathrm{PO}_{2}$ & Partial pressure of oxygen \\
\hline $\mathrm{CaO}_{2}$ & Arterial oxygen content & psi & Pounds per square inch pressure \\
\hline $\mathrm{DO}_{2}$ & Oxygen delivery & Q & Cardiac output \\
\hline OHDC & Oxyhemoglobin dissociation curve & $\mathrm{SaO}_{2}$ & $\begin{array}{l}\text { Oxygen saturation on cooximetry (e.g. using arterial } \\
\text { blood gas analysis) }\end{array}$ \\
\hline $\mathrm{PaCO}_{2}$ & $\begin{array}{l}\text { Partial pressure of carbon dioxide in arterial } \\
\text { blood }\end{array}$ & $\mathrm{ScvO}_{2}$ & Central venous oxygen saturation \\
\hline $\mathrm{PAO}_{2}$ & Partial pressure of oxygen in alveoli & $\mathrm{SJO}_{2}$ & Jugular venous oxygen saturation \\
\hline $\mathrm{PaO}_{2}$ & Partial pressure of oxygen in arterial blood & $\mathrm{SpO}_{2}$ & Oxygen saturation on pulse oximetry \\
\hline PB & Barometric pressure & $\mathrm{SvO}_{2}$ & Mixed venous oxygen saturation \\
\hline $\mathrm{PH}_{2} \mathrm{O}$ & Partial pressure of water vapor at $37^{\circ} \mathrm{C}$ & $\mathrm{VO}_{2}$ & Oxygen consumption \\
\hline
\end{tabular}

Table 1: List of abbreviations

() The Author(s). 2019 Open Access This article is distributed under the terms of the Creative Commons Attribution 4.0 International License (https://creativecommons. org/licenses/by-nc/4.0/), which permits unrestricted use, distribution, and non-commercial reproduction in any medium, provided you give appropriate credit to the original author(s) and the source, provide a link to the Creative Commons license, and indicate if changes were made. The Creative Commons Public Domain Dedication waiver (http://creativecommons.org/publicdomain/zero/1.0/) applies to the data made available in this article, unless otherwise stated. 
Flowchart 1: Diffusion of oxygen from plasma to RBC and binding to hemoglobin. (Drawn with permission from www.gotheextramile.com - Quiz Time in Critical Care Pty Ltd, Sydney, Australia)

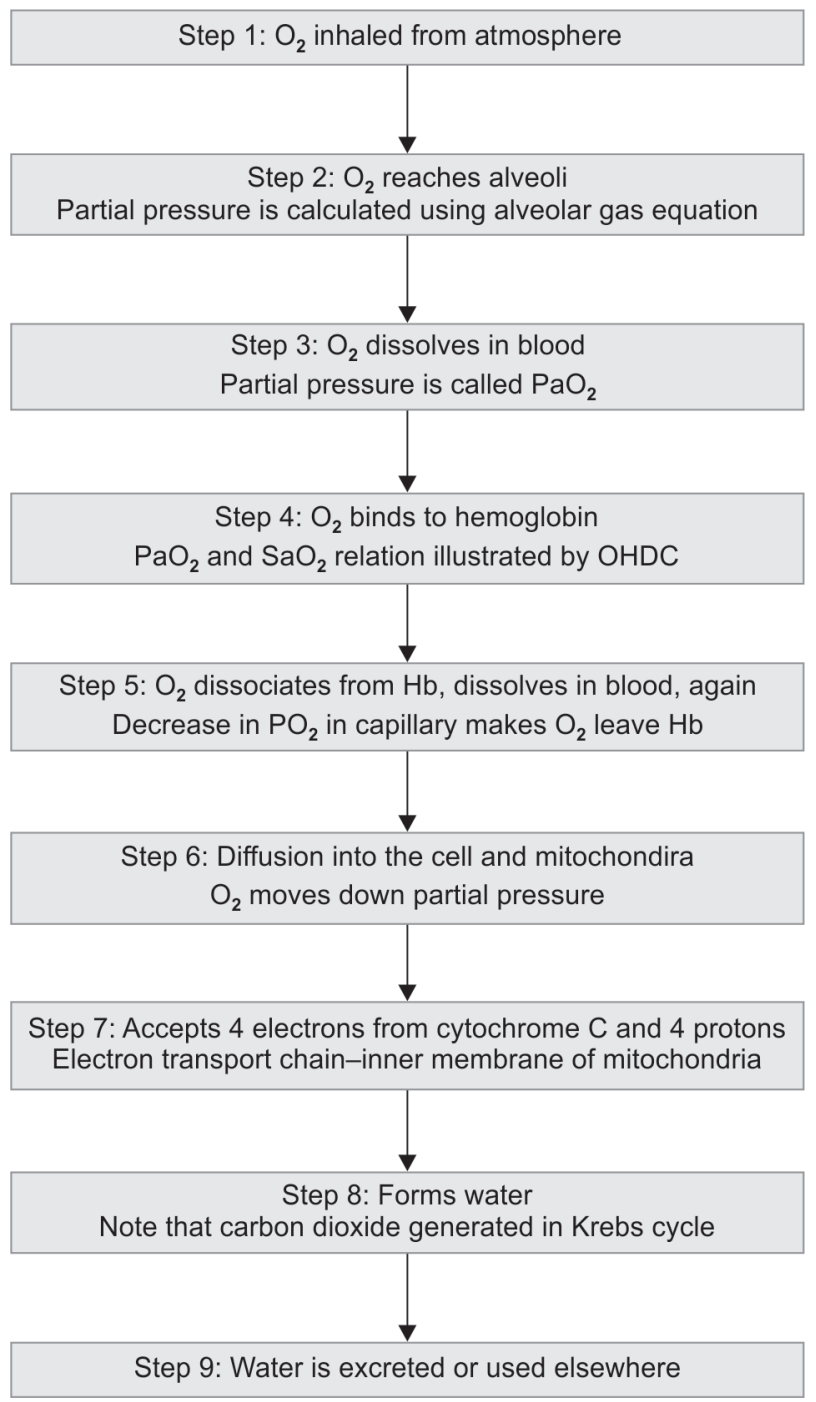

partial pressure of oxygen that it is exposed to. This relationship is known as Henry's law. The difference between $\mathrm{PAO}_{2}$ and $\mathrm{PaO}_{2}$ is popularly called 'A-a' gradient.

\section{Oxygen Binds to Hemoglobin}

How much oxygen binds to hemoglobin, and therefore how much oxygen is carried by blood, is determined by $\mathrm{PaO}_{2}$. In pulmonary capillaries blood, $\mathrm{PO}_{2}$ is high; therefore, hemoglobin takes up oxygen dissolved in plasma (Fig. 2). Plasma in turn draws more oxygen from the alveoli.

Each hemoglobin molecule has four protein chains, carrying a heme molecule. In deoxyhemoglobin, the hemoglobin molecule is in a 'tense' conformation having relatively low affinity for oxygen. In oxyhemoglobin, it adopts a relaxed state and the affinity for oxygen increases than in the 'tense' state. The combination of oxygen to first heme increases the affinity of second heme for oxygen and so on.

The relationship between $\mathrm{PaO}_{2}$ and $\mathrm{SaO}_{2}$ when plotted on a graph results in a sigmoid-shaped curve commonly known as the oxygen hemoglobin dissociation curve (OHDC). Binding of oxygen to hemoglobin also depends on certain factors like $\mathrm{PaCO}_{2}, \mathrm{pH}$ temperature and 2, 3 Diphosphoglycerate (DPG) levels in RBCs. These factors lead to either a rightward or leftward shift of the OHDC. The $\mathrm{PO}_{2}$ at which hemoglobin is $50 \%$ saturated is called the $\mathrm{P}_{50}$ (normally $27 \mathrm{~mm} \mathrm{Hg}$ in adult) and is used to measure the shift. Thus, depending on other variables, $\mathrm{SaO}_{2}$ may vary for the same $\mathrm{PaO}_{2}$ value. Various physiological parameters that result in a shift in OHDC are illustrated in Figure 3.

It should be noted that only small amount of oxygen is transported in dissolved form. For $\mathrm{Hb}$ of $15 \mathrm{~g} / \mathrm{dL}$, at $100 \%$ saturation and $\mathrm{PaO}_{2}$ of 100 , approximately $20 \mathrm{~mL} / \mathrm{dL}$ is transported bound to hemoglobin while only $0.3 \mathrm{~mL} / \mathrm{dL}$ is transported dissolved in blood (1 $\mathrm{dL}=100 \mathrm{~mL}$ ). Oxygen content of blood may be calculated using the following equation.

$$
\begin{aligned}
& \mathrm{CaO}_{2}=\mathrm{Hb} \text { bound } \mathrm{O}_{2}+\text { Dissolved } \mathrm{O}_{2} \\
& \mathrm{CaO}_{2}=\left(\mathrm{Hb} \times \mathrm{K} \times \mathrm{SaO}_{2}\right)+\left(\alpha \times \mathrm{PaO}_{2}\right)
\end{aligned}
$$

$\mathrm{K}$ is Huffner's constant $\left(1.39 \mathrm{~mL} \mathrm{O}_{2}\right.$ /gram $\left.\mathrm{Hb}\right)$ - Maximum amount of oxygen that can bind to $\mathrm{Hb}$

$\alpha$ is the solubility coefficient for $\mathrm{O}_{2}$ at $37^{\circ} \mathrm{C}(0.00314 \mathrm{~mL} / \mathrm{dL} /$ $\mathrm{mm} \mathrm{Hg}$ ).

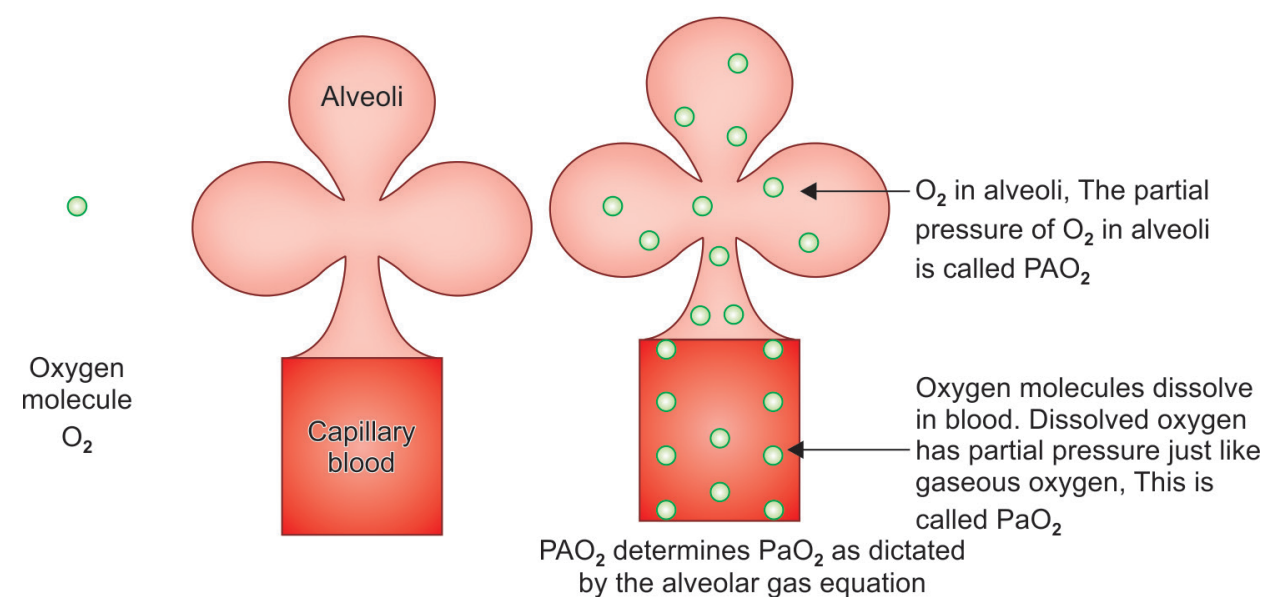

Fig. 1: Entry, transport in blood and metabolic role of oxygen 

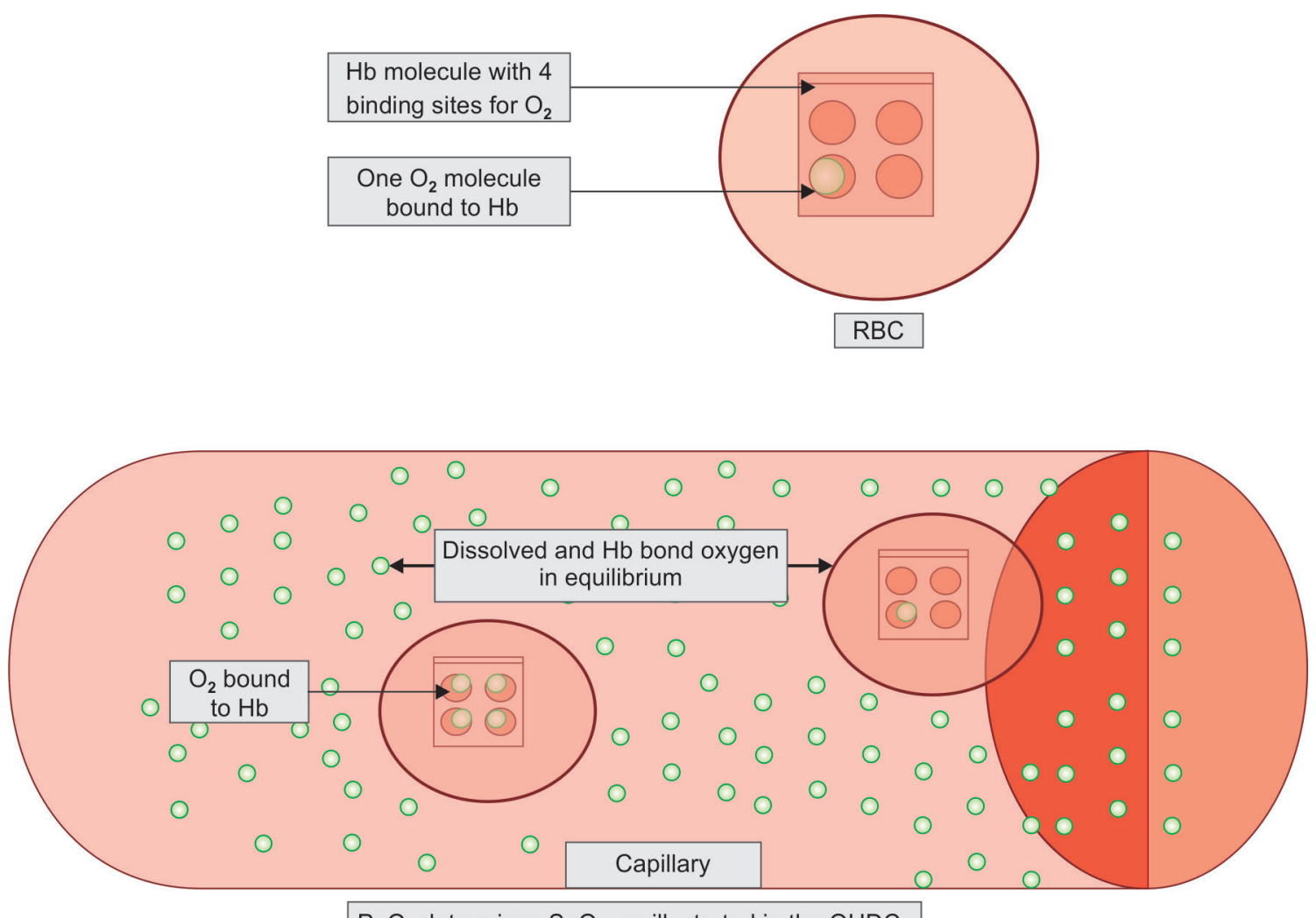

$\mathrm{PaO}_{2}$ determines $\mathrm{SaO}_{2}$, as illustrated in the $\mathrm{OHDC}$

Fig. 2: Diffusion of oxygen from alveoli to plasma (Drawn with permission from www.gotheextramile.com - Quiz Time in Critical Care Pty Ltd, Sydney, Australia)

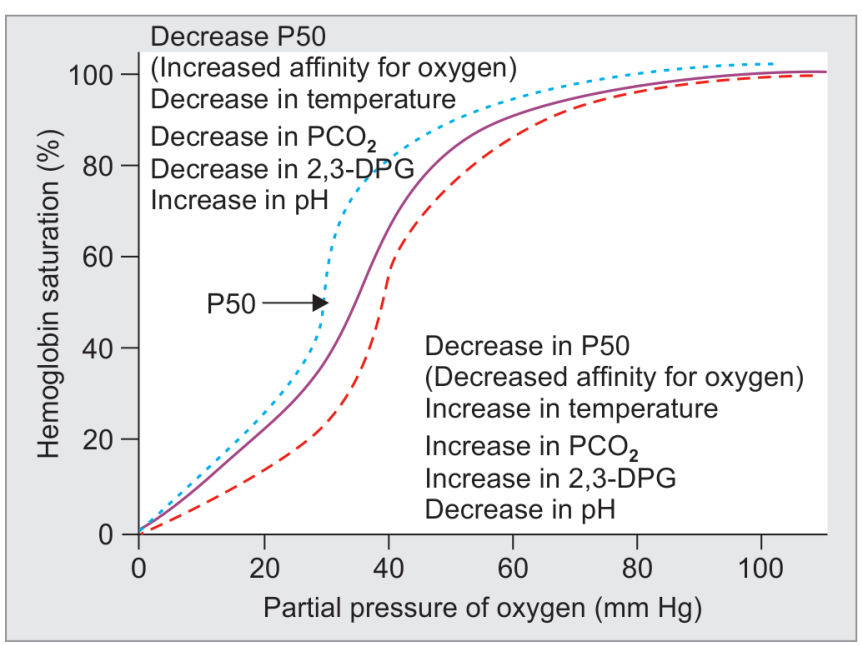

Fig. 3: Oxyhemoglobin dissociation curve and factors that results in a shift to right or left (Drawn with permission from www.gotheextramile. com - Quiz Time in Critical Care Pty Ltd, Sydney, Australia)

\section{Hemoglobin Releases Oxygen in Capillaries}

In the tissue cells, the $\mathrm{PO}_{2}$ is low. As a result, oxygen dissolved in the capillary blood diffuses into the tissues. This reduces the capillary oxygen $\mathrm{PO}_{2}$, which decreases the affinity of oxygen for hemoglobin. In the capillaries, therefore, oxygen dissociates from hemoglobin and diffuses down the concentration gradient into the cells.

\section{Oxygen Entry into Cell and Metabolic Pathway}

Oxygen enters the cells and is primarily utilized via cytochrome-C oxidase in electron transport chain located in the inner mitochondrial membrane. Here, one molecule of oxygen accepts 4 hydrogen nuclei (protons) and 4 electrons, resulting in formation of two molecules of water and ATP. Note that carbon dioxide is produced in the Krebs cycle and contains the oxygen molecule derived from glucose. Oxidative metabolism of each glucose molecule results in production of 38 ATP. When the level of oxygen in mitochondria falls to around 1-2 $\mathrm{mm} \mathrm{Hg}$ (Pasteur point), oxidative phosphorylation stops. Anaerobic metabolism of glucose results in synthesis of lactic acid yielding just 2 ATP per glucose. Other enzymes like cytochrome P450 hydroxylase also utilize oxygen and are involved in detoxification.

\section{Oxygen Delivery}

Since limited amount of oxygen is stored in the body, the cells depend upon continuous supply of oxygen by blood. The oxygen delivered per minute to cells is roughly 4 times the oxygen consumption. Oxygen delivery $\left(\mathrm{DO}_{2}\right)$ refers to the amount of oxygen delivered by blood to the tissues every minute.

$$
\mathrm{DO}_{2}=\mathrm{Q} \times \mathrm{CaO}_{2}
$$

Oxygen consumption may be calculated by subtracting oxygen content in venous blood from that in arterial blood

Oxygen extraction ratio

$$
\mathrm{VO}_{2}=\mathrm{Q} \times\left(\mathrm{CaO}_{2}-\mathrm{CvO}_{2}\right)
$$

$$
\mathrm{ER}=\mathrm{VO}_{2} \div \mathrm{DO}_{2}
$$

When $\mathrm{DO}_{2}$ is moderately reduced, $\mathrm{VO}_{2}$ remains normal because of increased oxygen extraction. With further reductions in $\mathrm{DO}_{2}$, 
Physiology of Oxygen Transport and its Determinants in ICU

Table 2: Effect of exposure to hypobaric and hyperbaric conditions on oxygen transport

\begin{tabular}{|c|c|c|c|}
\hline Condition & Pathophysiological Effects & $\begin{array}{l}\text { Response to change in Pressure/ } \\
\text { Treatment }\end{array}$ & Comment \\
\hline High altitude & $\begin{array}{l}\mathrm{FiO}_{2} \text { remains same } \\
\mathrm{PiO}_{2} \text { decreases - At Mt Everest } \\
\left(8848 \mathrm{~m} \text { ) the } \mathrm{PiO}_{2} \text { is } 43 \mathrm{~mm}\right. \\
\mathrm{Hg} \text { (equivalent to } \mathrm{FiO}_{2} 0.06 \text { at } \\
\text { sea level, } \mathrm{PaO}_{2} \text { and } \mathrm{SaO}_{2} \text { drops } \\
\text { proportionately) }\end{array}$ & $\begin{array}{l}\text { Hyperventilation reduces } \mathrm{PaCO}_{2} \text {. } \\
\text { Acclimatization results in increase in } \\
\text { hemoglobin concentration }\end{array}$ & $\begin{array}{l}\text { Sudden exposure to high altitude } \\
\text { (decompression of aeroplane) results in rapid } \\
\text { hypoxia and loss of consciousness. } \\
\text { Commercial flights cruising at altitude of } \\
30,000 \text { feet are pressurized to } 11 \text { psi when the } \\
\text { outside pressure is } 4 \text { psi. } 11 \text { psi is equivalent to } \\
\mathrm{FiO}_{2} 0.16 \text { at sea level }\end{array}$ \\
\hline $\begin{array}{l}\text { Hyperbaric } \\
\text { oxygen therapy }\end{array}$ & $\begin{array}{l}\mathrm{FiO}_{2} \text { remains same } \\
\mathrm{PiO}_{2} \text { increases - At } 2 \\
\text { atmospheres, } \mathrm{PiO}_{2} \text { even at } \mathrm{FiO}_{2} \\
0.21 \text { is } 309 \mathrm{~mm} \mathrm{Hg} \text { (equivalent to } \\
\mathrm{FiO}_{2} 0.4 \text { at sea level). } \\
\mathrm{PaO}_{2} \text { and } \mathrm{SaO}_{2} \text { increases } \\
\text { proportionately } \\
\text { Increase in solubility of oxygen } \\
\text { in blood with increase pressure } \\
\text { (Henry's law) }\end{array}$ & $\begin{array}{l}\text { At } \mathrm{FiO}_{2} 1 \text {, at } 1 \text { atm. pressure, } \\
2 \mathrm{~mL}^{\mathrm{dL}} \mathrm{L}^{-1} \mathrm{O}_{2} \text { is dissolved in plasma } \\
\mathrm{At} \mathrm{FiO}_{2} 1 \text { at } 3 \text { atm. Pressure, } 6 \mathrm{~mL}^{-\mathrm{dL}^{-1}} \\
\mathrm{O}_{2} \text { dissolved in plasma, equal to } \\
\text { arteriovenous oxygen difference. } \\
\text { The pressure rises by } 1 \text { atm for } \\
\text { every } 10 \text { meters depth under water. } \\
\text { To reduce risk of decompression } \\
\text { sickness, divers should ascend } \\
@<30 \text { feet per minute }\end{array}$ & $\begin{array}{l}\text { Hyperbaric oxygen therapy is used for } \\
\text { treatment of decompression sickness, arterial } \\
\text { air embolism, carbon monoxide poisoning, } \\
\text { anaerobic infections (clostridial myonecrosis, } \\
\text { etc.), chronic wounds, radiation osteonecrosis, } \\
\text { etc. }\end{array}$ \\
\hline
\end{tabular}

a critical point is reached beyond which $\mathrm{VO}_{2}$ becomes directly proportional to $\mathrm{DO}_{2}$. This state of supply-dependence is associated with progressive lactic acidosis caused by cellular hypoxia.

\section{Applied Physiology of Oxygen Transport IN BLOOD}

\section{How does Alteration in Ambient Pressure Alter the Oxygen Carriage in the Blood?}

At sea level, body is exposed to atmospheric pressure of $760 \mathrm{~mm}$ $\mathrm{Hg}$. Altered ambient pressure can have profound effects on oxygen carrying ability of blood. The effects of exposure to hyperbaric or hypobaric conditions is outlined in Table 2.

\section{Measurement of Oxygen Carriage - Pulse Oximetry and ABG Analysis}

\section{How does Pulse Oximetry Differ from Arterial Blood Gas} Analysis?

Pulse oximetry measurement is based on spectrophotometry. Spectrophotometry utilizes the ratio of absorption of light of specific wavelength by oxyhemoglobin and reduced hemoglobin to calculate their respective concentration. Most pulse oximeters use light at two wavelengths -660 and 940 nanometers. Using Lambert-Beer law, concentration of oxyhemoglobin is measured from the ratio of transmitted light and incident light from pulsatile blood. It should be noted that when we say that $\mathrm{SpO}_{2}$ is $90 \%$, it means there is 90 parts oxyhemoglobin out of 100 parts oxyhemoglobin plus reduced hemoglobin.

Arterial blood gas analysis uses co-oximetry. Co-oximetry is spectrophotometry technique that utilizes multiple wavelengths (as opposed to only two in pulse oximetry), so that accurate concentration of oxyhemoglobin, reduced hemoglobin, carboxyhemoglobin and methemoglobin can be measured. Co-oximetry is the gold standard for oxygen saturation measurement. It should be noted that when we say that $\mathrm{SaO}_{2}$ is $90 \%$, it means there is 90 parts oxyhemoglobin out of 100 parts oxyhemoglobin, reduced hemoglobin, carboxy hemoglobin and methemoglobin.

\section{When is Pulse Oximetry Inaccurate?}

The accuracy of pulse oximeter is based on the following assumptions: Firstly, the oxyhemoglobin and reduced hemoglobin are the only substances that absorb light at the wavelengths used, and secondly, the arterial pulsations are the only cause of pulsatile blood flow. When these assumptions cannot be satisfied, accurate measurement of oxyhemoglobin fraction cannot be made. True hypoxia may exist even when pulse oximeter reading is within normal range. Oxygen saturation gap is the difference between the oxygen saturation calculated from a blood gas machine and that from a pulse oximeter. ${ }^{1}$ If the gap is $>5 \%$, abnormal hemoglobin, e.g. carboxyhemoglobin should be suspected. For example, carboxyhemoglobin has similar absorption at $660 \mathrm{~nm}$ as oxyhemoglobin, but not at $940 \mathrm{~nm}$. Even in presence of high carboxyhemoglobin concentration, pulse oximeter continues to read about $90 \%$. Increasing concentration of methemoglobin, on the other hand, results in decrease in $\mathrm{SpO}_{2}$, until it reaches a plateau at about $85 \%$. Fetal hemoglobin or sickle hemoglobin do not alter signal on pulse oximetry. Methylene blue, sometimes used as a rescue therapy in shock, may result in sudden decrease in $\mathrm{SpO}_{2}$ without true arterial hypoxia. In patients with shock, when the pulsatile flow is weak, the pulse oximeters amplify the signal. This results in amplification of the background noise as well, resulting in inaccurate reading.

\section{Can Arterial Blood Gas Sample Give Erroneous Oxygen Saturation Result?}

\section{Air Bubble or Froth}

Room air bubbles have $\mathrm{PO}_{2}$ of about $150 \mathrm{~mm} \mathrm{Hg}$. Change in $\mathrm{PaO}_{2}$ depends upon initial $\mathrm{PaO}_{2}$ in the blood sample. At low $\mathrm{Hb}$ saturation $\left(\mathrm{PaO}_{2}<70\right.$ or $\left.\mathrm{SaO}_{2} \sim 93 \%\right)$ oxygen absorbed from air bubble binds to the $\mathrm{Hb}$, with minimal change in $\mathrm{PaO}_{2}$. If initial blood $\mathrm{PaO}_{2}$ is 80-140 mm Hg, exposure to air increases $\mathrm{PaO}_{2}$. For initial $\mathrm{PaO}_{2}$ $>150$, exposure to air decreases $\mathrm{PaO}_{2}$. Air bubbles or froth should be expelled from the syringe before transport. Pneumatic transport system (The CHUTE) results in agitation of sample and a thorough mixing of air bubble with blood, resulting in excessive change in the $\mathrm{PaO}_{2}$ compared delivery by personnel. 
Physiology of Oxygen Transport and its Determinants in ICU

Table 3: Effects and compensatory mechanisms due to hypoxia

\begin{tabular}{ll}
\hline Compensatory mechanism & Comment \\
\hline $\begin{array}{l}\text { Hyperventilation } \\
\text { Hypoxic pulmonary vasoconstriction }\end{array}$ & $\begin{array}{l}\text { Hyperventilation increases the oxygen demand of the diaphragm itself. } \\
\text { Redistribution of pulmonary blood flow for better ventilation-perfusion match. Increase in pulmo- } \\
\text { nary vascular resistance may not be well tolerated in right ventricular failure }\end{array}$ \\
$\begin{array}{l}\text { Increased cardiac output } \\
\text { Rightward displacement of OHDC stimulation due to activation of chemoreceptors in aortic and carotid body }\end{array}$ & $\begin{array}{l}\text { Increase in regional blood flow to most organ beds, particularly, brain } \\
\text { Increase in 2,3 DPG and acidosis }\end{array}$ \\
$\begin{array}{l}\text { Lactate production to maintain regenerate NAD from NADH and maintain glycolysis (which pro- } \\
\text { duces } 2 \text { ATP/glucose). In the absence of production of lactate, glycolysis will stop, and } 2 \text { molecules } \\
\text { of ATP generated during glycolysis will no longer be available. While lactate is used as a marker of } \\
\text { ischemia, its production is essential and may preserve life by anaerobic metabolism in the absence } \\
\text { of oxygen. }\end{array}$ \\
Activation of erythropoietin and transferrin gene
\end{tabular}

Delay in Transfer of Blood to the Lab

In a blood sample awaiting transfer to the lab $\mathrm{PaO}_{2}$ decreases due to respiration of the blood cells, particularly the WBC and reticulocytes. Samples that cannot be analyzed within 10 minutes should be stored on crushed ice and analyzed within 30 minutes. The change in $\mathrm{pH}$, bicarbonate, and base excess is not significant for up to 30 minutes. There is an upward trend in $\mathrm{PaCO}_{2}$, but the change is not significant at 30 minutes. $^{2}$

\section{How does Hypothermia Affect $\mathrm{PaO}_{2}$ on $A B G$ ?}

Level of oxygen in a solution is measured using Clarke's electrode. Routinely, blood gas is analyzed at $37^{\circ} \mathrm{C}$. Care is required when analyzing the $A B G$ of a hypothermic patient. In alpha-stat strategy the sample is analyzed at $37^{\circ} \mathrm{C}$ while in the $\mathrm{pH}$-stat strategy measurement be corrected to the actual core body temperature.

If blood sample of hypothermic, patient is warmed to $37^{\circ} \mathrm{C}$ (Alpha-stat), decrease in affinity of $\mathrm{Hb}$ at higher temperature (due to right shift of OHDC) results in release of large amount of oxygen, resulting in overestimation of $\mathrm{PaO}_{2}$. On the other hand, if the blood sample is analyzed at same temperature as body $(\mathrm{pH}-$ Stat), $\mathrm{PaO}_{2}$ will be lower because of higher solubility of oxygen at lower temperature. However, even with low $\mathrm{PaO}_{2}$, the hemoglobin saturation may be higher (due to left shift in OHDC). A simple rule of thumb may be to decrease $\mathrm{PaO}_{2}$ by $5 \mathrm{~mm} \mathrm{Hg}$ for each $1^{\circ} \mathrm{C}$ drop in temperature.

\section{How can We Increase the Capacity of Blood to Deliver Oxygen?}

Ensuring that the tissues receive adequate oxygen is a big part of what we do in intensive care. A detailed discussion is beyond the scope of this review. A few points are worth mention.

- Supplemental oxygen: The use of supplemental oxygen is so common that we forget it is a drug, with side effects. Supplemental oxygen is vital for treatment of hypoxemia. However, routine use in the absence of hypoxia provides no benefit. The IOTA metanalysis (Improving Oxygen Therapy in Acute-Illness) suggests that liberal oxygen therapy increases mortality without improving any patient-centered outcome. ${ }^{3}$

- Iron: It is useful for absolute iron deficiency. Many critically ill patients have anemia of inflammation, for which supplemental iron is not useful. Iron is important for bacterial growth and may increase infection risk. Iron supplementation has not been shown to reduce transfusion requirements. ${ }^{4}$
- Erythropoietin appears to be attractive, particularly when restrictive transfusion trigger is used. Its use does not reduce the number of units transfused. Erythropoietin supplementation has not been shown to reduce transfusion requirements.

- Oxygen carriers: Hemoglobin-based oxygen carriers (HBOC) and perfluorocarbons are being studied but not yet used in clinical practice. ${ }^{5}$

\section{Hypoxia - Causes, Signs and Compensation}

Hypoxemia $\left(\mathrm{PaO}_{2}<80 \mathrm{~mm} \mathrm{Hg}\right)$ presents with vague symptoms and may be difficult to detect unless looked for the compensatory mechanisms that get activated in the setting of hypoxemia are listed in Table 3.

\section{When should Venous Oxygen Content be Measured?}

- Mixed venous oxygen saturation $\left(\mathrm{SvO}_{2}\right)$ refers to the oxygen saturation in mixed venous blood returning from all parts of the body, including heart. For $\mathrm{SvO}_{2}$ measurement, blood should be sampled from the distal port of pulmonary artery catheter. Its normal value is between $60 \%$ and $80 \%$. If hemoglobin concentration, $\mathrm{SaO}_{2}$ and oxygen consumption remain constant, decrease in $\mathrm{SvO}_{2}$ reflects a decrease in cardiac output.

- Central venous oxygen saturation $\left(\mathrm{ScvO}_{2}\right): \mathrm{ScvO}_{2}$, when measured in blood drawn from a central vein in superior vena cava, is $2-4 \%$ lower than $\mathrm{SvO}_{2}$ because the blood from kidneys is less deoxygenated. During period of hemodynamic instability, renal and splanchnic blood flow may be lower, and the relationship between $\mathrm{SvO}_{2}$ and $\mathrm{ScvO}_{2}$ will change. The two, therefore, cannot be used interchangeably. ${ }^{6}$ The heart has a higher oxygen extraction, and blood from coronary sinus has lower oxygen saturation than from central venous blood.

- Jugular venous oximetry $\left(\mathrm{SjO}_{2}\right)$ is sometimes used in patients with acute neurological injury. The catheter is inserted in the jugular vein but directed cephalad. The normal value ranges from 55-75 mm Hg. Low $\mathrm{SjO}_{2}$ indicates cerebral ischemia. High $\mathrm{SjO}_{2}$ may indicate either cerebral hyperemia, or reduced cerebral metabolism, as may occur after brain death.

\section{What can Cause the Blood to Boil at $37^{\circ} \mathrm{C}$ ?}

We finish the article with a piece of useless trivia. Metaphorically, even trivial things may make our blood boil, but it can really boil if 
the ambient pressure is so low that the gas dissolved in blood start to form bubbles. Ebullism, as it is technically called, will occur at an altitude of 29,000 m (Armstrong's line). The astronaut space suits are pressurized to prevent its occurrence.

\section{References}

1. Akhtar J, Johnston BD, Krenzelok EP. Mind the gap. J Emerg Med. 2007 Aug;33(2):131-132.

2. Biswas CK, Ramos JM, Agroyannis B, Kerr DN. Blood gas analysis: effect of air bubbles in syringe and delay in estimation. Br Med J (Clin Res Ed). 1982 Mar 27;284(6320):923-927.
3. Chu DK, Kim LH, Young PJ, Zamiri N, Almenawer SA, Jaeschke R, et al. Mortality and morbidity in acutely ill adults treated with liberal versus conservative oxygen therapy (IOTA): a systematic review and meta-analysis. Lancet. 2018 Apr 28;391(10131):1693-1705.

4. Shah A, Roy NB, McKechnie S, Doree C, Fisher SA, Stanworth SJ. Iron supplementation to treat anaemia in adult critical care patients: a systematic review and meta-analysis. Crit Care. 2016 Sep 29;20(1):306.

5. French C. Erythropoietin in Critical Illness and Trauma. Crit Care Clin. 2019 Apr;35(2):277-287.

6. Barratt-Boyes BG, Wood EH. The oxygen saturation of blood in the venae cavae, right-heart chambers, and pulmonary vessels of healthy subjects. J Lab Clin Med. 1957 Jul;50(1):93-106. 